\title{
"ROZTOCZE - WITALNOŚĆ Z NATURY" BRAND AS AN INDICATOR OF ABIOTIC ASSETS IN MARKETING SLOGANS AND TOURISM PRODUCTS
}

\section{TERESA BRZEZIŃSKA-WÓJCIK}

Maria Curie Skłodowska University in Lublin Faculty of Earth Sciences and Spatial Management tbrzezin@poczta.umcs.lublin.pl

\section{JEL CODE \\ KEYWORDS}

ABSTRACT
Z32

brand, abiotic assets, promotion, tourism product, Roztocze region

The study presents the results of evaluation of the "Roztocze - Witalność z natury" brand as an indicator of the abiotic assets of the region reflected in marketing slogans and tourism products. The study goals were achieved using the query and stocktaking methods, screening, and analysis of opportunities for development. The results indicate that the most frequently mentioned abiotic elements include landscape (hills, valleys, and Cretaceous, Eocene, and Miocene rock outcrops) and recreational (groundwaters) assets. There is no indication of specialist assets. The abiotic assets are most widely identified in Roztocze Tomaszowskie. The marketing slogans mainly refer to recreational (streams, Roztocze wave, kayaks, sunny beaches) and landscape (quarries, rock and fossil outcrops) assets. The tourism offer proposes primarily trail-products; in turn, there are no area-products or object-products evoking memories of the brand and Roztocze as a tourist region.

\section{Introduction}

Given the dynamically changing economic situation, a tourism brand (Kozak, Baloglu, 2011; Fedyk, Gruszka, Krajewska-Smardz, 2014) is created by many regions to attract potential visitors (Dwyer, Chulwon, 2003). In these areas, the brand symbolises a promise of what can be expected from a region and product (Pringle, Gordon, 2008) and what will satisfy visitors' expectations (Walas, 2001). Therefore, a recognisable set of material, non-material, and functional assets is created to 
distinguish the tourist region (Wanagos, 2012) and constitute the brand's identity (Łuczak, 2011). In relation to the area, the brand should be broadly interpreted as a set of activities targeted at the regional tourism product (Lewandowska, Panasiuk, 2005). In terms of the tourism market, the brand is directly associated with the tourism offer and should be understood as its traits perceived by consumers (Panasiuk 2014). It provides buyers with emotional and functional benefits symbolising the uniqueness of the area/product and influencing the purchasing process (Kaczmarek, Stasiak, Włodarczyk, 2010).

The "Roztocze - Witalność z natury" brand was designed by the Local Tourist Organisation Roztocze (LTO) in 2010. The organisation includes local government institutions from two of the four Roztocze subregions, i.e. Tomaszów county, Tomaszów Lubelski town, and Bełżec, Krynice, Susiec, Tomaszów Lubelski, Tarnawatka, and Jarczów communes in Roztocze Tomaszowskie as well as Narol town and commune and Lubycza Królewska commune in Roztocze Rawskie. It also brings together entrepreneurs from these administrative units. The concept of the brand is based on activities aimed at enhancement of the recognition of the entire region as an area that is able to fulfil the promise of healthy and active recreation in nature.

In terms of tourism, the Roztocze region has already been evaluated in terms of the use of abiotic and biotic assets in the current functional tourism offer for development of the concept of the area product (Brzezińska-Wójcik, 2017, 2018a). Additionally, the "Roztocze - Witalność z natury" brand has been assessed as an indicator of biotic assets reflected in marketing slogans and tourism products (Brzezińska-Wójcik, 2018b). However, some questions arise: to what extent does the brand "Roztocze - Witalność z natury" identify the abiotic assets of the entire region in terms of tourism products? Does this brand actually promote products that are characteristic for the entire region, as promised (Strategia marki ..., no publication year). To address these questions, we focused only on abiotic assets in the brand structure as heritage constituting the attractiveness of the Roztocze region (one of the six elements proposed by A. Panasiuk (2013).

Therefore, the aim of the study was to evaluate the extent to which the "Roztocze - Witalność $z$ natury" brand is an indicator of abiotic assets of the region present in marketing slogans and tourism products.

\section{Material and method}

In the first stage of the study, secondary source materials (literature; publication Oferty turystyczne - Region Lubelski. Polska 2018/2019; tourist information leaflets with the brand logo; tourist magazine Magiczne Roztocze; other promotional publications including cartographic materials) were subjected to the query method. The next stage consisted in analysis of the results of abiotic asset stocktaking from 2016-2018.

Next, marketing slogans and tourism products associated with the abiotic assets of Roztocze were collected, classified, and analysed. The analysis of the data was carried out in the following categories: 1) marketing slogans promoting brand-related abiotic assets of the entire Roztocze 
region and its subregions; 2) abiotic assets in marketing slogans and tourism products in Roztocze sub-regions promoted by the brand.

In the final stage, a description combined with other methods (historical analysis and analysis of development possibilities) were used to determine the degree of identification of the abiotic assets in the entire region by the "Roztocze - Witalność z natury" brand.

\section{Features of abiotic assets in the Polish part of Roztocze}

The Roztocze subregions proposed by J. Buraczyński (1995) in functional terms (Lijewski, Mikułowski, Wyrzykowski, 2002) are characterised by landscape, recreational, and specialist assets.

The group of landscape assets formed by nature is dominated by relief forms ( 92 including springs - 29, gorges, rocks, and caves - 10 each, valleys and knickpoints in some of them - 7), geological outcrops (70 including Miocene rocks - 32 and Late Cretaceous rocks - 22), monuments of nature (32 including springs - 22 and rocks - 9) (Brzezińska-Wójcik, 2017, 2018a).

The landscape assets created by nature and man include museums and nature collections (12). Most of them are located in Roztocze Tomaszowskie - Ośrodek Edukacyjno-Muzealny Roztoczańskiego Parku Narodowego [Educational and Museum Centre of the Roztoczański National Park] in Zwierzyniec, Muzeum Kamieniarstwa im. Adama Grochowicza [Adam Grochowicz Masonry Museum] and Pawilon geoturystyczny [Geotourism Pavilion] in Józefów, Muzeum Przyrodniczo-Etnograficzne „Zagroda Guciów” [Natural and Ethnographic Museum "Guciów Grange”] in Guciów, and Muzeum Wsi Krasnobrodzkiej i Muzeum GeologicznoGarncarskie [Krasnobród Village and Geology-Pottery Museum] in Krasnobród. The most distinctive collections associated with the geological heritage can be found in Muzeum Skamieniatych Drzew [Petrified Trees Museum] in Siedliska, Roztocze Rawskie (Brzezińska-Wójcik, 2017).

Natural landscape assets with a character and importance unaffected by human activity are represented by viewing platforms (17). They are mainly concentrated in Roztocze Szczebrzeszyńskie (Brzezińska-Wójcik, 2017).

The recreational assets comprise sets of features that are indispensable (clean air, silence, low level of urbanisation, aesthetic values of the landscape, no basic climatic contraindications) and advantageous (landscape scenic assets, conditions for active recreation in summer and winter, favourable bioclimatic conditions, medicinal assets) (Lijewski et al., 2002).

In Roztocze, the set of indispensable features is associated with abiotic assets, which are largely satisfactory. The region belongs to class A (concentration levels not exceeding the permissible level) in terms of ozone and benzo(a)pyrene air pollution in accordance with the relevant regulations of the Minister of the Environment (13 September 2012 - on assessment of levels of substances in the air, Journal of Laws of 24 August 2012, item 1032 - on the levels of some substances in the air; 2 August 2012 - on zones of assessment of air quality, Journal of Laws item 914; Stan środowiska..., 2014). As shown by data for 2016, particulate pollutants are retained (95.1-99.0\%) by pollution control devices (Atlas statystyczny..., 2018). 
The advantageous features in Roztocze include landscape assets. In terms of genetics, loess and carbonate landscapes are predominant (Chmielewski, Sowińska-Świerkosz, Kułak, Chmielewski, 2014). A majority of the assets are areas with a natural or nearly natural landscape (category I assets) (Bogdanowski, 1971). The landscape assets are enhanced by the diversity of relative heights. Areas with the highest maximum denivelation values $(>78.0 \mathrm{~m})$ are most frequent in Roztocze Szczebrzeszyńskie and Roztocze Gorajskie but occur less frequently in Roztocze Tomaszowskie (Brzezińska-Wójcik, 2017).

The opportunity of water-related recreation in Roztocze is limited due to the contamination of fragments of the Wieprz, Tanew, and Sołokija rivers (Raport..., 2018).

In turn, the region is outstanding in the Lublin upland belt for the length of the ski hiking period (50-60 days) and downhill skiing (30-40 days) (Wyrzykowski, 1984). In terms of the downhill skiing conditions, the only criterion that is not met is the $150-\mathrm{m}$ difference in altitudes (Główne problemy..., 1973).

Biometeorological factors promote recreation in Roztocze as well. In the scale of Poland, the region is distinguished in terms of solar radiation in the second half of summer and early autumn as well as the highest average number of sunny days, i.e. approximately 47 on its northern slope (Kaszewski, 2008). Therefore, it represents the warmest, moderately stimulus-related anthropoclimatic regions (Kozłowska-Szczęsna, 1991). As shown by the comprehensive indicator of weather for recreation $(W R I)$, the region is characterised by the shortest period of non-recreational weather in Poland (only in December) and a shift of the onset of highly favourable weather to early May (Błażejczyk, Kunert, 2011). Furthermore, the level of scattered ultraviolet radiation in the warm half of the year creates great opportunities for heliotherapy (Kuczmarski, 1984).

The properties of groundwaters containing high amounts of calcium and magnesium bicarbonates are associated with the features of fractured Late Cretaceous and Miocene rocks (Michalczyk, 1996; Chmiel, Michalczyk, Turczyński, 1997). Additionally, there are sulphurous mineral waters with therapeutic properties (Ciężkowski, Porwisz, Zuber, 2003) near Horyniec-Zdrój.

The canoeing and speleological assets available in Roztocze are important in terms of the suitability of the abiotic assets for specialist tourism forms.

However, only some rivers (Wieprz and Tanew) and a few artificial reservoirs are suitable for water tourism. The group of objects that are not yet adapted for tourists' visits comprises caves (Piekiełko, Kolegów i Przyjaciół in Polanka Horyniecka, Chmielna in Niwki Horynieckie, Diabelska near Wola Wielka, Niedźwiedzia in Werchrata, Grota w Studni on Monastyr hill) located in Roztocze Rawskie (Mleczek, 2009).

\section{Marketing slogans proposed by the brand and promoting the entipe region and/or subregions based on abiotic assets}

The advertising panel of the brand (http://roztoczewita.pl/marka-roztocze/) shows 19 photographs with six pictures presenting abiotic assets. Hence, the analysed region should be associated with the closed quarry in Nowiny, petrified wood in the Museum in Siedliska, knickpoints in the Tanew 
river, a stone watchtower in Susiec, a water reservoir, and sand (http://www.roztoczewita.pl/ lot-roztocze/marka-roztocze).

In 2012-2018, the "Roztocze - Witalność z natury" brand promoted abiotic assets of the entire region via only two marketing slogans. Earlier (in 2012), the area was promoted with a slogan "Roztocze. Tu chodzi się boso" [Roztocze. You walk barefoot here] with reference to the diversified relief, the colours of Roztocze sun-drenched fields, knickpoints in riverbeds, and higher insolation than in other regions of Poland. In the following years (2016-2017), the slogan was changed into "Jak zostać zdrowym leniem?" [How to become a healthy lazybones?] with the same reference to the high insolation and picturesque rivers. The fresh air was promoted as well (Magiczne Roztocze, 2012, 2016, 2017).

In their marketing messages "Roztocze. Tu chodzi się boso" [Roztocze. You walk barefoot here] and "List z wakacji na Roztoczu" [A letter from holiday in Roztocze], the slogans promoting the abiotic assets of the Roztocze regions mentioned the gorges in Roztocze Szczebrzeszyńskie, the quarry in Józefów and thresholds (waterfalls, knockpoints) in the Tanew river near Susiec in Roztocze Tomaszowskie, and the Petrified Trees Museum in Siedliska and mineral waters in Roztocze Rawskie (Magiczne Roztocze, 2012, 2013, 2015, 2016). The slogans did not refer to the abiotic assets of Roztocze Gorajskie.

Thus, in the promotional messages referring to the entire Roztocze area and its subregions, the brand offers the tourist only some landscape assets, i.e. mainly the riverbed knickpoints.

\section{Ahiotic assets characteristic for Roztocze subregions promoted by the brand in marketing slogans and tounism products}

The abiotic assets of the subregions are promoted by the brand with three slogans. In Roztocze Gorajskie, these are "Kajakowe Roztocze” [Kayak Roztocze] and „Gdzie strumyk płynie z wolna...” [Where the stream flows slowly...], which popularise event-products (kayaking) in two valleys (Łada and Por rivers). The same marketing messages popularise three valleys (Wieprz, Sołokija, and Tanew) in Roztocze Tomaszowskie. Two of them (Wieprz and Tanew) are also promoted with the slogan "Na Roztoczańskiej fali” [On the Roztocze wave] (Roztocze. Informator..., 2010, 2011; Magiczne Roztocze, 2013, 2014, 2015, 2016, 2017).

Thus, only some landscape assets characteristic for the subregions, i.e. valleys, are promoted by the brand. Event-products, i.e. the cyclical National Canoe Tour "Rzeki Roztocza" [Roztocze Rivers] on the Wieprz and Sołokija rivers in Roztocze Tomaszowskie and the International Roztocze Bike Ride in Roztocze Rawskie, are the only promoted products, however without mentioning nature resources. 


\section{Abiotic assets in the communes of Roztocze subpegions promoted by the brand in marketing slogans and tourism products}

The assets of four (Batorz, Chrzanów, Janów Lubelski, Radecznica) among the 11 communes in Roztocze Gorajskie are promoted by the brand. They mainly include river valleys (Por, Łada, Gorajec) promoted in marketing slogans "Białe szaleństwo" [White frenzy] and "Na Roztoczańskiej fali" [On the Roztocze wave]. Only linear tourism products, i.e. downhill skiing trails (in Batorz and Chrzanów), are promoted. Additionally, the brand mentions Porytowe Wzgórze via a slogan "Szlaki konne" [Horse-riding trails] in the "Cwał" [Gallop] trail-product (Informator..., 2011; Magiczne Roztocze, 2013, 2014, 2017).

In Roztocze Tomaszowskie, the brand promotes assets in a majority (6) of the 11 communes (Adamów, Józefów, Krasnobród, Susiec, Tomaszów Lubelski, Zwierzyniec). The assets identified include primarily hills (Młynarka, Kamień, Hołda, Biała Góra, Wapielnia, Kamienna Góra) in five communes (except for Adamów) and valleys (Jacnia, Sopot, Tanew, and Jeleń rivers and Siwa Dolina) in four communes (except for Krasnobród and Zwierzyniec). Outcrops of Miocene rocks (in Józefów, Szopowe, Nowiny, Potok Senderki) located in three communes (Józefów, Krasnobród, Susiec) and artificial water reservoirs (on Wieprz, Sopot, and Świerszcz rivers) located in three communes (Krasnobród, Susiec, Zwierzyniec) are mentioned relatively frequently.

In terms of the repeatability of the promoted assets in this subregion, the marketing message about Krasnobród commune is characterised by the greatest richness - hills, Miocene and Cretaceous rocks, springs, artificial water reservoirs, as well as climatic and landscape assets. Tomaszów Lubelski commune advertised with its hills, Siwa Dolina Valley, Eocene rocks, and springs is in the second place in this respect.

Hills are referred to in seven marketing slogans - "Białe szaleństwo" [White frenzy], "Natura [Nature], "Rowerem po Roztoczu” [Cycling in Roztocze], "Dwa kółka na Roztoczu [Two wheels in Roztocze], "Szlaki konne" [Horse-riding trails], "Wędrowanie" [Hiking], and "Wędrujemy" [Our hikes]. Valleys are promoted in three repeating messages - "Białe szaleństwo" [White frenzy], "Wędrowanie" [Hiking], and "Wędrujemy" [Our hikes]. Rock outcrops are referred to in the slogan "Historia zaklęta w kamieniu" [History captivated in stone] and artificial water reservoirs are promoted by a phrase "Słoneczne plaże Roztocza" [Sunny beaches of Roztocze] (Roztocze. Informator... 2010, 2011; Magiczne Roztocze 2012, 2013, 2014; Powiat Tomaszowski-mapa ... [no publication year]; Susiec na Roztoczu ... [no publication year]; Informator turystyczny powiatu ... [no publication year]; sub-tab "pomniki przyrody i inne miejsca" [nature monuments and other places] on the brand's website).

Trails are the main tourism products mentioned. A majority of these products are bicycle trails, including "Centralny Szlak Rowerowy Roztocza" [Roztocze Central Cycling Trail] and "Trasa Rowerowa Ziemi Józefowskiej” [Józefów Land Cycling Trail]. There are single object/area-products, i.e. the geotourism pavilion in Józefów and Sztolnie near Krasnobród (Roztocze. Informator... 2010, 2011; Magiczne Roztocze 2013, 2014). 
The assets of all three communes in Roztocze Rawskie are promoted by the brand, with the greatest promotion of the assets located in Lubycza Królewska commune. These include petrified Miocene tree trunks (marsh cypress) in Siedliska, hills (Goraje - Krągły and Długi), and the Sołokija river valley. In the other two communes, the promotion is focused on groundwaters, hills, and valleys (Roztocze. Informator... 2010, 2011; Magiczne Roztocze, 2012, 2013, 2014).

The hills are advertised by the marketing slogan "Wędrujemy" [Our hikes], the valleys - with two marketing messages "Rowerem po Roztoczu" [Cycling in Roztocze] and "Dwa kółka na Roztoczu" [Two wheels in Roztocze], and the groundwaters - by three slogans - "Smaki Roztocza" [Roztocze flavours], "Swojskie klimaty" [Familiar vibes], and "Borowinowe eldorado" [Peloid Eldorado]. Trails, i.e. "Nad Brusienką" [On the Brusienka river], "Nad Sołokiją" [On the Sołokija river], "Na kamiennym szlaku Roztocza" [On the Roztocze stone trail], and "Szlak p.o. Goraje" [Goraje trail], are the most frequently mentioned tourism products (Roztocze. Informator... 2010, 2011; Magiczne Roztocze, 2012, 2013, 2014).

Summing up, the greatest brand promotion of the communes of the subregions can be noted for landscape assets created by nature, i.e. relief forms (hills, valleys) and Miocene rock outcrops. The second place is occupied by recreational assets, i.e. artificial water reservoirs on the Wieprz, Sopot, and Świerszcz rivers. The most numerous tourism products are represented by cycling trails ("Centralny Szlak Rowerowy Roztocza” [Roztocze Central Cycling Trail], "Na kamiennym szlaku Roztocza" [On the stone Roztocze trail], and "Trasa Rowerowa Ziemi Józefowskiej” [Józefów Land Cycling Trail]). There are single object/area-products. The brand "Roztocze - Witalność z natury" does not take into account the abiotic assets in Roztocze Szczebrzeszyńskie.

\section{Conclusions}

Among the abiotic assets, the "Roztocze - Witalność z natury" brand most often mentions landscape assets (hills - in 15 slogans and 13 products, valleys - in 12 slogans and in 10 products, and Cretaceous, Eocene and Miocene rock outcrops - in 9 slogans and 7 products) and recreational assets (groundwaters - in 5 slogans and 2 products). There is no reference to specialist assets.

The marketing slogans refer mainly to recreational (stream, Roztocze wave, kayaks, and sunny beaches) and landscape (quarries, rock and fossil outcrops) assets.

The analysis of the lists of offers promoted by LROT (Oferty turystyczne..., 2018/2019) indicates that only one of 19 tourism offers in Lublin Province, i.e. the trail-product "Spływy kajakowe Wieprzem" [Wieprz river canoeing] is labelled with the logo of the "Roztocze - Witalność z natury" brand.

The study results indicate that the brand offers trail-products most frequently but rarely events, objects, and dishes. It does not promote any area-product or thing-products that could evoke memories associated with the brand and Roztocze as a tourist region. This is important because such identifiers (material souvenirs) are remembered easily for a long time by the tourist through visualgustatory associations, which results in "experiencing" the tourism product. Products that are characteristic of Roztocze Tomaszowskie are identified by the brand most largely. 
The Roztocze products promoted by the brand are highly similar and repetitive, which was underlined by E. Dziedzic (1998), who carried out a comparison with other regions. Consequently, tourists are concentrated in certain linear systems or in very small areas.

The marketing activities described in the study indicate that the "Roztocze - Witalność z natury" brand is a communicator (destination brands as communicators perspective), as specified by G. Hankinson (2004, p. 113). However, there is no targeted long-term strategy of communication between the brand and its recipients. On the supra-regional scale, only some object-products associated with the abiotic assets are recognisable in Roztocze. These include the artificial water reservoir in Horyniec-Zdrój - ca. 12\% and ca. 11\% of indications (respectively: Tabor 2009, Rydzewski 2012), the artificial reservoir in Krasnobród, "Stawy Echo" [Echo Ponds], kayaking (along the Wieprz and Tanew), Muzeum Skamieniałych Drzew [Petrified Trees Museum] in Siedliska, and the "Babia Dolina" Quarry in Józefów (Kula, 2012).

As demonstrated by the study results, the marketing messages should make better use of the landscape assets such as inanimate nature monuments (in particular - springs), museums and nature collections (as a variant for bad weather), or viewing platforms (not included in the slogans or products). Recreational assets should also be included, especially those constituting indispensable features.

"Roztocze - Witalność z natury" has a chance to become a strong tourist brand (Woods, Deegan, 2003), with which local stakeholders will identify provided it creates a wide range of assets, including cultural assets with their adequately promoted relationships with nature.

The results of the analysis of the marketing message of the brand can also be treated as recommendations for its designers, especially for the website as an important marketing tool (Pilarczyk 2010). There is a need for creation of a sub-tab "bioclimatic conditions" presenting maximum and minimum temperature values, precipitation rates (impact of rain on tourism, skiing conditions), persistence of the snow cover, and insolation (heliotherapy). There is no sub-tab "waters" with division into "surface waters" (rivers, water reservoirs) and "groundwaters", while other tabs present many offers of active kayaking recreation. The "health in Roztocze" sub-tab does not specify the properties of the mineral waters or the therapeutic and relaxing properties of the climate that are the basis for the function of the Horynie-Zdrój and Krasnobród health resorts, respectively.

Translated by Anna Zoń

\section{Referennces}

Atlas statystyczny Polski (2018). Warsaw: Główny Urząd Statystyczny.

Błażejczyk, K., Kunert, A. (2011). Bioklimatyczne uwarunkowania rekreacji i turystyki w Polsce. Warsaw: Instytut Geografii i Przestrzennego Zagospodarowania im. Stanisława Leszczyckiego Polskiej Akademii Nauk.

Bogdanowski, J. (1971). Wstępne rozeznanie krajobrazów o przewadze elementów naturalnych i kulturowych (mapa). Warsaw: Biuletyn Komitetu Przestrzennego Zagospodarowania Przestrzennego Polskiej Akademii Nauk, book 68.

Brzezińska-Wójcik, T. (2017). Zasoby przyrody nieożywionej Roztocza jako podstawa kreowania obszarowego produktu turystycznego. Zeszyty Naukowe Wyższej Szkoły Turystyki i Języków Obcych w Warszawie. Turystyka i Rekreacja, $2(20), 5-22$. 
Brzezińska-Wójcik, T. (2018a). Use of biotic resources of Roztocze in tourism offers in the context of the theoretical concept of tourism area product. Polish Journal of Natural Sciences, 3 (33), 455-485.

Brzezińska-Wójcik, T. (2018b). Marka „Roztocze - Witalność z natury” jako identyfikator walorów przyrody ożywionej regionu w hasłach marketingowych i produktach turystycznych. Prace Naukowe Uniwersytetu Ekonomicznego we Wrocławiu, 535, 9-25.

Buraczyński, J. (1995). Regiony geomorfologiczne Roztocza. Annales Universitatis Mariae Curie-Skłodowska, B, 48, 59-73.

Chmiel, S., Michalczyk, Z., Turczyński, M. (1997). Ocena jakości wód podziemnych i powierzchniowych Roztocza. Annales Universitatis Mariae Curie-Skłodowska, B, 52, 77-102.

Chmielewski, T., Sowińska-Świerkosz, B., Kułak, A., Chmielewski, S. (2014). Krajobrazy Roztocza: dziedzictwo natury i kultury. Lublin: Uniwersytet Przyrodniczy w Lublinie.

Ciężkowski, W., Porwisz, B., Zuber, A. (2003). Geneza i wiek wód siarczkowych Horyńca Zdroju i Ratoszyna. Współczesne Problemy Hydrogeologii, 9 (part 2), 95-102.

Dwyer, L., Chulwon, K. (2003). Destination competitiveness: determinants and indicators. Current Issues in Tourism, 5 (6), 369-413.

Dziedzic, E. (1998). Obszar recepcji turystycznej jako przedmiot zarządzania strategicznego. Warsaw: Szkoła Główna Handlowa.

Fedyk, W., Gruszka, I., Krajewska-Smardz, A. (2014). Ocena wizerunku marki turystycznej Polski według opinii obcokrajowców. Rozprawy Naukowe Akademii Wychowania Fizycznego we Wrocławiu, 45, 196-203.

Główne problemy rozwoju turystyki zimowej w Polsce. Materiaty z Ogólnopolskiego Seminarium zorganizowanego przez Pracownię Krakowska Zakładu Zagospodarowania Turystycznego GKKFiT w dniach 18 i 19 IV 1972 w Krakowie (1973). Warsaw: Instytut Turystyki.

Hankinson, G. (2004). Relational network brands: Towards a conceptual model of place brands. Journal of Vacation Marketing, 2 (10), 109-121.

Informator turystyczny powiatu tomaszowskiego [no publication year]. Tomaszów Lubelski: Powiat Tomaszowski.

Kaczmarek, J., Stasiak, A., Włodarczyk, B. (2010). Produkt turystyczny. Warsaw: Polskie Wydawnictwo Ekonomiczne.

Kaszewski, B.M. 2008. Klimat. In: S. Uziak, R. Turski (eds.), Środowisko Przyrodnicze Lubelszczyzny (pp. 75-111). Lublin: Lubelskie Towarzystwo Naukowe.

Klasyfikacja gmin pod względem występowania zagrożeń środowiska (weryfikacja obszarów ekologicznego zagrożenia) (1995). Warsaw: Główny Inspektorat Ochrony Środowiska.

Kozak, M., Baloglu, S. (2011). Managing and marketing tourism destinations: strategies to gain a competitive edge. New York: Routledge.

Kozłowska-Szczęsna, T. (1991). Antropoklimat Polski (próba syntezy). Zeszyty Instytutu Geografii i Przestrzennego Zagospodarowania Polskiej Akademii Nauk, l (1), 1-64.

Kuczmarski, M. (1984). Możliwości wykorzystania usłonecznienia do celów helioterapii w Polsce. Dokumentacja Geograficzna, 1-2, 117-137.

Kula, S. 2012. Percepcja i wykorzystanie walorów turystycznych Roztocza przez osoby odwiedzające region. In: D. Jegorow, A. Niedużak (eds.), Wpływ sektora B+R na wzrost polskiej konkurencyjności polskiej gospodarki poprzez rozwój innowacji, t. 1 (pp. 55-65). Chełm: Wydawnictwo CIVIS.

Lewandowska, A., Panasiuk, A. (2005). Marka turystyczna. In: A. Panasiuk (ed.), Marketing ustug turystycznych (pp. 88-91). Warsaw: Wydawnictwo Naukowe PWN.

Lijewski, T., Mikułowski, B., Wyrzykowski, J. (2002). Geografia turystyki Polski. Warsaw: Polskie Wydawnictwo Ekonomiczne.

Łuczak, M. (2011). Branding miejsca turystycznego na przykładzie Gdańska. Zeszyty Naukowe Uniwersytetu Szczecińskiego, 663. Ekonomiczne problemy usług, 75, 73-87.

Magiczne Roztocze (2012). Zamość: Biuro Turystyczne QUAND.

Magiczne Roztocze (2013). Zamość: Biuro Turystyczne QUAND.

Magiczne Roztocze (2014). Zamość: Biuro Turystyczne QUAND.

Magiczne Roztocze (2015). Zamość: Biuro Turystyczne QUAND. 
Magiczne Roztocze (2016). Zamość: Biuro Turystyczne QUAND.

Magiczne Roztocze (2017). Zamość: Biuro Turystyczne QUAND.

Magiczne Roztocze (2018). Zamość: Biuro Turystyczne QUAND.

Marka „Roztocze witalność z natury”. Zamość: Lokalna Organizacja Turystyczna Roztocze. Retrieved from: http://www. roztoczewita.pl/lot-roztocze/marka-roztocze (15.02.2018).

Michalczyk, Z. (ed.), (1996). Źródła Roztocza. Monografia hydrograficzna. Lublin: Wydawnictwo Uniwersytetu MariiSkłodowskiej Curie.

Mleczek, T. (2009). Jaskinie Roztocza Południowego - stan rozpoznania. In: M. Szelerewicz, J. Urban, R. Dobrowolski (eds.), Materiaty 43. Sympozjum Speleologicznego. Zamość, 24-25.

Oferty turystyczne - Region Lubelski, 2018/2019. Lublin: Wydawnictwo Lubelska Regionalna Organizacja Turystyczna.

Panasiuk, A. (ed.) (2013). Marketing $w$ turystyce i rekreacji. Warsaw: Wydawnictwo Naukowe PWN.

Panasiuk, A. (2014). Rynek turystyczny. Studium strukturalne. Warsaw: Difin.

Pilarczyk, B. (2010). Komunikacja marketingowa jako sposób osiagania przewagi konkurencyjnej na rynku, In: B. Pilarczyk, Z. Waśkowski (eds.), Komunikacja rynkowa - skuteczne narzędzia i obszary zastosowania (pp. 117-126). Poznań: Wydawnictwo Uniwersytetu Ekonomicznego w Poznaniu.

Pringle, H., Gordon, W. (2008). Zarządzanie marka. Jak wypromować rozpoznawalna markę. Rebis: Poznań.

Raport o stanie środowiska województwa lubelskiego w 2017 roku (2018). Lublin: Biblioteka Monitoringu Środowiska.

Roztocze. Informator turystyczny (2010-2011). Tomaszów Lubelski: Wydawnictwo Lokalnej Organizacji Turystycznej „Roztocze".

Rydzewski, P. (2012). Perspektywy rozwoju gospodarczego oraz aktywność zawodowa mieszkańców gminy HoryniecZdrój. Raport z badań. Lublin: Wyższa Szkoła Przedsiębiorczości i Administracji w Lublinie.

Stan środowiska w Polsce. Raport 2014 (2014). Warsaw: Biblioteka Monitoringu Środowiska.

Strategia marki regionu Roztocze (no publication year). Niemce: Synergia sp. z o.o.

Tabor, K. (2009). Turystyka uzdrowiskowa na przykładzie Horyńca Zdroju. In: A. Balińska (ed.) Potencjał turystyczny regionów (pp.109-117). Warsaw: Wydawnictwo FAPA.

Walas, B. (2001). Marka turystyczna miast i regionów. Rynek Turystyczny, 11-12.

Wanagos, M. (2012). Kształtowanie wizerunku miasta na przykładzie działań samorządowych Gdyni. Zeszyty Naukowe Uniwersytetu Szczecińskiego, 709. Problemy Zarządzania, Finansów i Marketingu, 23, 299-313.

Woods, M., Deegan, J. (2003). A warm welcome for destination quality brand: the example of Pays Cathare region. International Journal of Tourism Research, 4 (5), 269-282.

Wyrzykowski, J. (1984). Optymalne okresy użytkowania turystycznego walorów wypoczynkowych środowiska przyrodniczego Polski. Acta Universitatis Wratislaviensis, 656. Studia Geograficzne, 44. 


\section{MARKA "ROZTOCZE - WITALNOŚĆ Z NATURY” JAKO IDENTYFIKATOR WALORÓW PRZYRODY NIEOŻYWIONEJ REGIONU W HASŁACH MARKETINGOWYCH I PRODUKTACH TURYSTYCZNYCH}

\author{
SŁOWA KLUCZOWE \\ STRESZCZENIE
}

potencjał turystyczny, funkcja turystyczna, Roztocze

Zaprezentowano wyniki badań nad oceną marki „Roztocze - Witalność z natury” jako wyróżnika walorów przyrody nieożywionej regionu w kontekście haseł marketingowych i produktów turystycznych. Założone cele zrealizowano stosując metody kwerendy i inwentaryzacji, odsiewu i analizy możliwości rozwoju. Uzyskane wyniki wskazują, że spośród walorów przyrody nieożywionej marka najczęściej przywołuje krajoznawcze (wzgórza, doliny, odsłonięcia skał kredowych, eoceńskich i mioceńskich) i wypoczynkowe (wody podziemne). Brakuje odniesienia do walorów specjalistycznych. W najszerszym zakresie identyfikuje walory przyrody nieożywionej Roztocza Tomaszowskiego. Hasła marketingowe nawiązują zwłaszcza do walorów wypoczynkowych (strumyk, roztoczańska fala, kajaki, słoneczne plaże) i krajoznawczych (kamieniołomy, ekspozycje skał i skamieniałości). Przeważnie proponowane są produkty-szlaki; brakuje produktu-obszaru oraz produktów-rzeczy przywołujących wspomnienia związane z marką i Roztoczem jako regionem turystycznym. 